\title{
A NOVEL SPHEROID MODEL FOR PRECLINICAL INTERCELLULAR NANOPHOTOSENSITIZER-MEDIATED TUMOR STUDY
}

\author{
Maklygina YuS ${ }^{1}$, Romanishkin ID1, Ryabova AV¹, Yakavets IV ${ }^{2,3}$, Bolotin L², Loschenov VB ${ }^{1,4}$ \\ Prokhorov General Physics Institute of the Russian Academy of Sciences, Moscow \\ ${ }^{2}$ Centre de Recherche en Automatique de Nancy (CRAN), Université de Lorraine, France \\ ${ }^{3}$ Belarusian State University, Minsk, Belarus \\ ${ }^{4}$ National Research Nuclear University «MEPhl», Moscow
}

\begin{abstract}
Aluminum phthalocyanine nanoparticles (NP AIPC) possess the features that make them a promising photosensitizer. In particular, AIPc NPs do not fluoresce in free nanoform, fluoresce weakly in normal tissue, strongly in tumors and very strongly in macrophages. Also, such particles fluoresce and become phototoxic when contacting certain biocomponents. The type of biocomponents that bind to AIPC NPS defines intensity, lifetime, and spectral distribution of the fluorescence. This study aimed to investigate the peculiarities of nanophotosensitizer capturing in 3D models of cell cultures. The data obtained demonstrate that AIPC NPs are captured by cells inside the spheroid in the course of the first hour, as the fluorescent signal's growth shows. Having analyzed the fluctuations of the fluorescence signal of AIPC NPs inside a spheroid, we have also discovered that the cellular 3D models are heterogeneous. Laser irradiation (two-photon excitation at $\lambda=780 / 390 \mathrm{~nm}$ ) resulted in photobleaching of fluorescence, which is probably associated with AIPC NP deactivation. Thus, the created model comprised of a 3D cell culture and AIPC NPs provides a better insight into metabolic processes in cells than monolayer 2D cell cultures. Besides, the model allows to evaluate the photodynamic effect depending on phenotypic properties of various areas in the heterogeneous 3D-structure.
\end{abstract}

Keywords: aluminum phthalocyanine, nanoparticles, nanophotosensitizer, multicellular tumor spheroid, laser scanning microscopy Funding: the study was supported by the Ministry of Education and Science of the Russian Federation (Agreement RFMEFI61618X0096 \#14.616.21.0096 of February 12, 2018).

Correspondence should be addressed: Yuliya S. Maklygina Vavilova 38, Moscow, 119991; us.samsonova@physics.msu.ru

Received: 26.06.2018 Accepted: 23.10.2018

DOI: $10.24075 /$ brsmu.2018.079

\section{ИССЛЕДОВАНИЕ СВОЙСТВ ТРЕХМЕРНОЙ КЛЕТОЧНОЙ МОДЕЛИ ОПУХОЛИ С ИСПОЛЬЗОВАНИЕМ НАНОФОТОСЕНСИБИЛИЗАТОРА В КАЧЕСТВЕ НОВОЙ ПРЕДКЛИНИЧЕСКОЙ МОДЕЛИ}

\author{
Ю. С. Маклыгина ${ }^{1}$, И. Д. Романишкин ${ }^{1}$, А. В. Рябова ${ }^{1}$, И. В. Яковец 2,3 , Л. Болотин², В. Б. Лощенов ${ }^{1,4}$ \\ Институт общей физики имени А. М. Прохорова Российской академии наук, Москва \\ ${ }^{2}$ Научно-исследовательский центр автоматики университета Лотарингии, Нанси, Франция \\ ${ }^{3}$ Белорусский государственный университет, Минск, Белоруссия \\ ${ }^{4}$ Национальный исследовательский ядерный университет «МИФИ», Москва
}

Ввиду своих особенностей наночастицы (НЧ), состоящие из фталоцианина алюминия (HЧ AIPC), являются перспективным фотосенсибилизатором. НЧ АІРc не флуоресцируют в свободной наноформе, слабо флуоресцируют в нормальной ткани, сильно - в опухолях и очень сильно - в макрофагах. НЧ АІРс обладают уникальной особенностью приобретать способность к флуоресценции и фототоксичности в контакте с некоторыми биокомпонентами. При этом тип биокомпонентов, связывающихся с НЧ AІPc, влияет на интенсивность, время жизни и спектральное распределение флуоресценции. Целью работы было исследовать особенности захвата нанофотосенсибилизатора в 3D-моделях клеточных культур. Полученные данные демонстрируют захват HЧ AІPс клетками внутри сфероида в течение первого часа по росту флуоресцентного сигнала. Обнаружена гетерогенность клеточных 3D-моделей по анализу изменения сигнала флуоресценции НЧ AІPc внутри сфероида. В результате лазерного облучения (двухфотонного возбуждения с $\lambda=780 / 390$ нм) наблюдали фротобличинг фрлуоресценции, который, вероятно, связан с деактивацией HЧ AІPc. Таким образом, созданная модель, состоящая из клеточной 3D-культуры с HЧ AlPc, позволяет лучше оценивать метаболитические процессы в клетках, чем монослойные клеточные 2D-культуры. Кроме того, модель позволяет оценивать фотодинамический эффект в зависимости от фенотипичных свойств различных областей в гетерогенной 3D-структуре.

Ключевые слова: фталоцианин алюминия, наночастицы, нанофотосенсибилизатор, многоклеточный опухолевый сфероид, лазерная сканирующая микроскопия

Финансирование: работа поддержана Министерством образования и науки Российской Федерации (соглашение RFMEFI61618X0096 № 14.616.21.0096 OT 12.02.2018).

4 Для корреспонденции: Юлия Сергеевна Маклыгина

ул. Вавилова, д. 38, г. Москва, 119991; us.samsonova@physics.msu.ru

Статья получена: 26.06.2018 Статья принята к печати: 23.10.2018

DOI: $10.24075 /$ vrgmu.2018.079 
Nanoparticles (NPs), which are based on molecular nanocrystals of photosensitizer (PS), are promising agents for the fluorescence diagnostics (FD) and treatment by the photodynamic therapy (PDT). Aluminium phthalocyanine (AIPC) nanocrystals have an advantage over the molecular PS used in clinic settings due to the significantly higher accumulation selectivity of nanoscale materials [1-4]. Moreover, they are able to fluoresce only in monomeric form upon the interaction of nanocrystals with biological structures, hereby providing appropriate FD detection efficiency [1, 2]. The type of interaction, the intensity, the lifetime and the spectrum of fluorescence depends on phenotype of the interacting cells. Fluorescence intensity of AIPc NPs in pathological tissue (inflammation, malignancy) significantly exceeds that in normal tissue [1, 2]. Moreover, AIPc NPs can be considered as theranostic probes providing both fluorescence for FD and photosensitizing activity for PDT treatment.

The in vitro screening of novel anti-cancer agents, particularly PSs, is mainly relied on photocytotoxicity assays using established cancer cell lines. Conventional twodimensional (2D) 2D cell cultures exhibit a rapid, uncontrolled growth phenotype and are not able to mimic the complexity and heterogeneity of in vivo tumors. Evidently, in vivo tumors grow in a three-dimensional conformation with a specific organization and architecture that a 2D monolayer cell culture cannot reproduce [5-7]. Three-dimensional (3D) cell cultures are considered as a more accurate and reproducible model for performing in vitro drug screening. This model displays several features of in vivo tumor tissues such as presence of extracellular matrix, intercellular interaction, hypoxia, drug penetration and resistance [8-10]. Therefore, in vitro spheroid model is an intermediate stage between conventional $2 \mathrm{D}$ in vitro testing and animal models. The sphe [11-13].

Thereby, we have chosen 3D multicellular spheroids as a model to study accumulation, distribution and PDT efficiency of AIPc NPs in HeLa cells.

\section{METHODS}

Multicellular spheroids were initiated by seeding $10^{4} \mathrm{HeLa}$ cells into 96-well plate previously coated with 1\% Agarose. Spheroid culture medium was changed every $2-3$ days. When spheroids reached $140 \pm 20 \mu \mathrm{m}$ in diameter after 7 days, they were used for experiments. In this study, aluminium phthalocyanine nanoparticles (AIPC NPs, $d \sim 100 \mathrm{~nm}, c=10 \mu \mathrm{g} / \mathrm{ml}$ ) were used as the PS. The investigations of AIPC fluorescence after different incubation intervals were performed using laser scanning confocal microscopy. For microscopy the spheroids were finally washed twice with pre-warmed phosphate buffered saline (PBS). The images were acquired with laser scanning microscope LSM-710-NLO (Zeiss; Germany). The 20x Plan-Apochromat objective with numerical aperture (NA) of 1.4 was used. The novel PS Aluminum phthalocyanine (AIPC) (synthesized by Organic Intermediates \& Dyes Institute (NIOPIK), Russia) was prepeared and studied using the spheroid model. The polycrystalline powder was added to distilled water to a concentration of $1 \mathrm{mg} / \mathrm{ml}$. The resulting suspension was dispersed in Bandelin SONOPLUS HD2070 ultrasonic homogenizer with KE76 attachment $(20 \mathrm{kHz}$, the amplitude of 165 microns) [2]. Using Photocor Complex (Russia) multi-angle spectrometer of the dynamic light scattering, allowing obtaining the nanoparticles distribution by size via the analysis of correlation function of the scattered light intensity fluctuations, it was found that the average particle diameter in the aqueous colloid was 100-150 nm. AlPc colloid ( $c=10 \mu \mathrm{g} / \mathrm{ml}$ ) was added to the medium of the spheroid model to mimic conditions of tumor cells interaction with PS NPs. The main AIPC NPs feature is the photoactivation ability. The primary AIPc colloid did not luminesce upon the laser excitation into the absorption band (at the wavelengths $633 \mathrm{~nm}$ and $780 \mathrm{~nm}$ by two-photon ex.) i.e. the PS nanocrystals in a free form showed no photoactivity. So, the nanoparticles colloid of AIPc was not initially photoactive and did not display fluorescent properties. However, during interaction of AIPC NPS with cells, the NPs are involving into metabolic cells processes and become photoactive $\left(\lambda_{\mathrm{ff}} \sim 670 \mathrm{~nm}\right.$ at the excitation $\lambda_{\text {ex }} \sim 633 \mathrm{~nm}$ and $780 \mathrm{~nm}$ by two-photon ex.).

Thus, the experiment protocol consisted of the following steps (Fig. 1.):

1) At the beginning of experiments, 10 spheroids have been transferred to separate Petri dish. After that the AIPc NPs colloid was added to a set of 10 spheroids at the concentration $10 \mu \mathrm{g} / \mathrm{ml}$ each. PS incubation was performed at $37^{\circ} \mathrm{C}$ for 15 min in the dark.

2) During futher incubation the cells autofluorescence was excited with $488 \mathrm{~nm}$ laser and simultaneously the AIPc NPs fluorescence was excited with $633 \mathrm{~nm}$ laser under the laser scanning microscope. After 1 hour of AIPs NPs accumulation the fluorescence signal stopped rising.

3) After that, the spheroids were washed twice with PBS and directly observed on an upright fluorescence microscope. Fluorescence images were recorded using 20x objective from the spheroid surface. After PS NPs interaction with biocomponents the NPs photoactivity was sufficient for the FD and PDT. Therefore, the detected interest zones were exposed to laser radiation with wavelength 780/390 nm (by two-photon excitation) after analysis of PS accumulation.

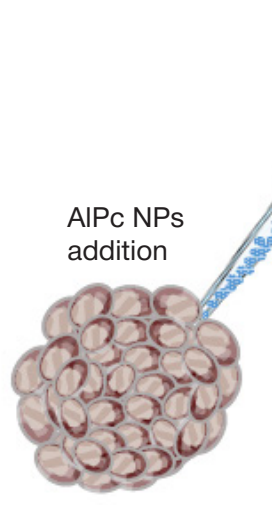

A

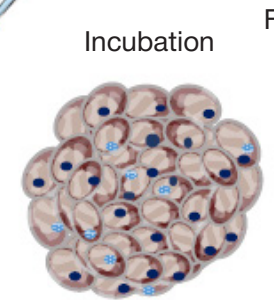

B

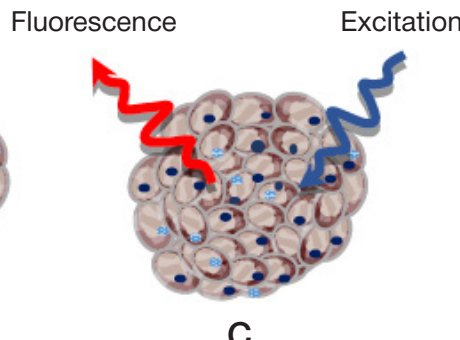

C
PDT

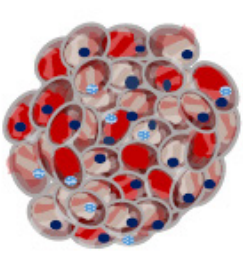

D

Fig. 1. The stepwise scheme of experiment with spheroid model and AIPC NPs 
4) Laser irradiations were performed at 780/390 nm (by two-photon excitation). The irradiation times were adapted for each irradiation. The assessement of photodynamic effect was realized analyzing the fluorescent signal after staining with acridine orange (for healthy cells detection - green; $\mathrm{AO}$, MolecularProbes $^{\circledR}$ ) and ethidium bromide (for dead cells detection - red; EB, MolecularProbes ${ }^{\circledR}$ ). For staining, the spheroids in PBS, previously washed from the culture medium, were incubated in the presence of working solution of dyes for 5 minutes. Stained spheroids from the 96-well plates for in vitro culture have been transferred to Petri dishes with a $0.17 \mathrm{~mm}$ glasse's thick in PBS solution. AO/EB fluorescence signals distribution was studied using confocal microscopy. Excitation of fluorescent $\mathrm{AO}$ was performed with a $488 \mathrm{~nm}$ laser, fluorescence was recorded in the range of $495-545 \mathrm{~nm}$. Excitation of fluorescent EB was performed with a $561 \mathrm{~nm}$ laser, fluorescence was recorded in the range of 580-690 nm. As a result, fluorescence images of AO (green) and EB (red) were obtained in the transmitted light mode. Thus, this stepwise approach enabled mimicing the conditions of tumor cells interaction with PS NPs at the first hour and the processes of FD and PDT with AIPc NPs in vivo.

\section{RESULTS}

AIPC NPs uptake in spheroids was evaluated at different times during 1 hour. An intense accumulation was observed during the first 30 minutes (Fig. 2A-C). After 40 minutes of incubation the fluorescence signal reached a plateau without considerable further changes (Fig. 2D-F). AlPc NPs fluorescence flaring up visualization in space and time allowed tracking of PS distribution. It was observed that after first 15 minutes AIPC NPs were accumulated in the peculiar regions at the periphery. Peripherical cells of spheroids had access to the NPs and could be primarly involved into endocytosis. It needed at least 15 minutes of incubation for the first uptake regions to be separated into irregularly shaped areas. Over the time these areas have rapidly grown directionlessly into the spheroid core
(Fig. 2C, D). After that, the nominal regions have shrunk into the single zone with minimal NPs uptake in the center (Fig. 2E). The time and spatial dynamic of AIPc NPs uptake described above could be explained by the heterogeneity of cells in 3D model in temrs of different metabolic processes and phenotypes. Otherwise, the AIPc NPs uptake would have been observed as uniform at the periphery and slightly decreasing towards the spheroid core concentrically.

The numerical estimation of PS uptake in various areas was obtained by recording fluorescence spectra (Fig. 3). Before starting the analysis it is worth introducing the equivalent diameter, needed in the presence of a non-perfect sphericity, and defined as the diameter of a circle with $150 \mu \mathrm{m}$, corresponding to the average spheroid's size and having the same area as the spheroid section being imaged. Thus, the total fluorescent signal from the single area was digitized and divided into the auto- and AIPC NPs fluorescent contributions (Fig. 3A, B). Autofluorescence signal was in the spectral range of $430-630 \mathrm{~nm}$, excited by the $\lambda_{\text {ex }} \sim 488 \mathrm{~nm}$. AIPC NPs fluorescence maximum was about $670 \mathrm{~nm}$, excited by the $\lambda_{\text {ex }} \sim 633 \mathrm{~nm}$ (Fig. 3). Analysis of spectra from the concentric regions had shown that the AIPC NPs uptake decreased with the autofluorescence increasing from the periphery to the center of spheroid (Fig. 3C).

At the same time the PS NPs uptake distribution was represented by the spheroid's sections of 4 projections to simplify visual perception, considering PS NPs fluorescence signal alone (Fig. 4). This also demonstrates the maximum of PS uptake in the periphery with local minimum in the center.

\section{DISCUSSION}

The penetration ability and phototoxicity of AIPc NPs was tested by the confocal laser scanning microscopy. Endocytosis was assumed to be the kind of uptake of NPs. The NPs penetration into the depth of the spheroid was observed over the first hour. However, under the assumption that the multicellular 3D model is homogeneous, NPs should be able to penetrate deep
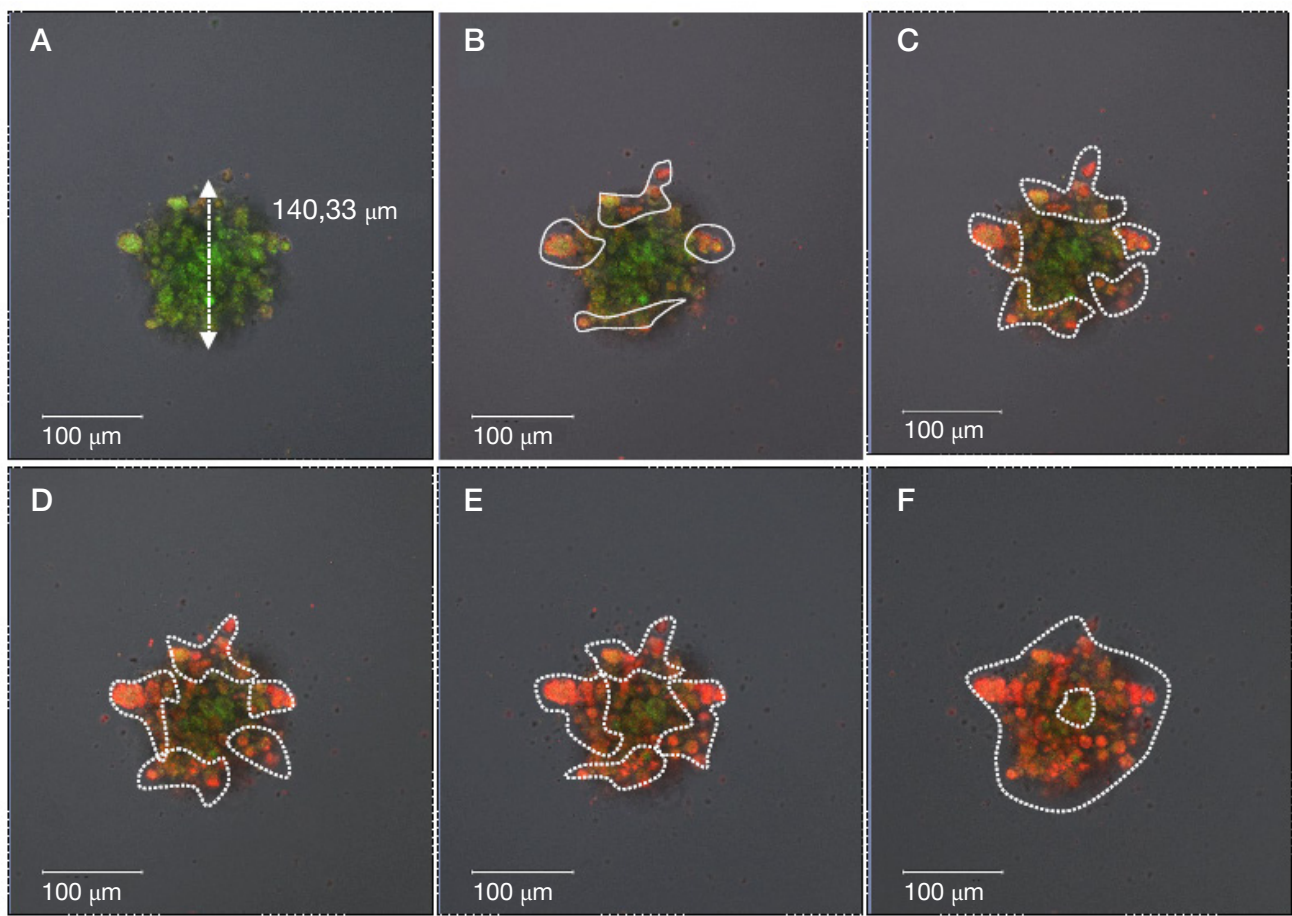

Fig. 2. Image of AIPc NP fluorescence flaring up over the time. Autofluorescence (green) excitation at $\lambda_{\text {ex }} \sim 488 \mathrm{~nm}$, AIPc NPs fluorescence (red) excitation at $\lambda_{\text {ex }} \sim 633$ nm: $15 \mathrm{~min}(\mathbf{A}) ; 20 \mathrm{~min}(\mathbf{B}) ; 30 \mathrm{~min}(\mathbf{C}) ; 40 \mathrm{~min}(\mathbf{D}) ; 50 \mathrm{~min}(\mathbf{E}) ; 1 \mathrm{~h} \mathrm{(F)}$ 
into the spheroids with a uniform volume distribution, which was not observed. So, likely, the uptake diversity in different spheroid's areas is due to the heterogeneity of spheroid model containing the cells of different phenotypes. This assumption is confirmed by the variety of the phototoxicity effect in the different spheroid's regions, depending on the presense of oxygen.

Therefore, the tumor model oxygenation was estimated indirectly. In this way, this model for investigating the uptake and photoinduced toxicity of AIPC NPs closely resembles in vivo tumors [14-15].

This result could be explained by the difference in the cells metabolic processes. Indeed, previous studies reported that an apoptotic core begins forming in spheroids of approximately 150-200 $\mu \mathrm{m}$ in diameter [16]. Similar to in vivo tumors, multicellular spheroids include hypoxic and apoptotic/ necrotic areas, developing as a consequence of the formation of oxygen and nutrient gradients. Remarkably, in spheroids, hypoxia occurs gradually over time, with the increase of the spheroid size [17]. Thus, the AIPc NPs uptake gradient could be explained by nutrient gradients and phenotype differences in the cells of $3 \mathrm{D}$ model. The degree of the molecular oxygen avalaibility in the different regions can be estimated by the rate of fluorescence signal decrease during the photodynamic irradiation upon the condition that phototoxicity depends on the presence of molecular oxygen. Phototreatment induces the energy transfer as a consecuence of PS fluorescence parching and also a production of active oxygen forms leading to cell death. The areas with a strong photodynamic effect were identified by a comparison of AIPC NPs fluorescence
A

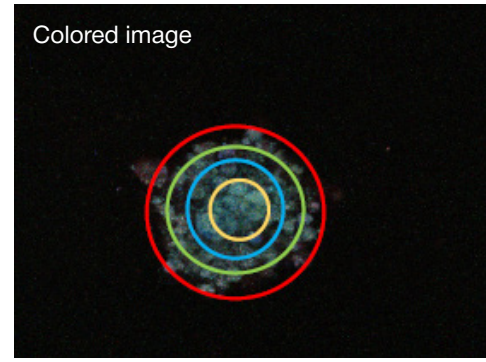

B

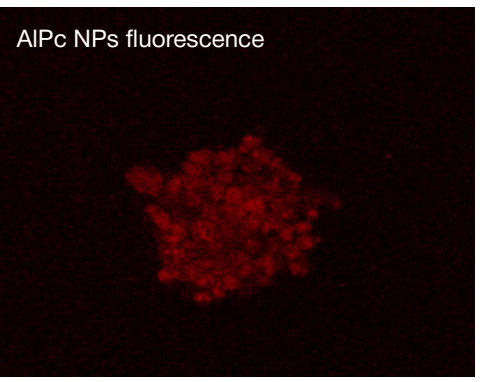

C

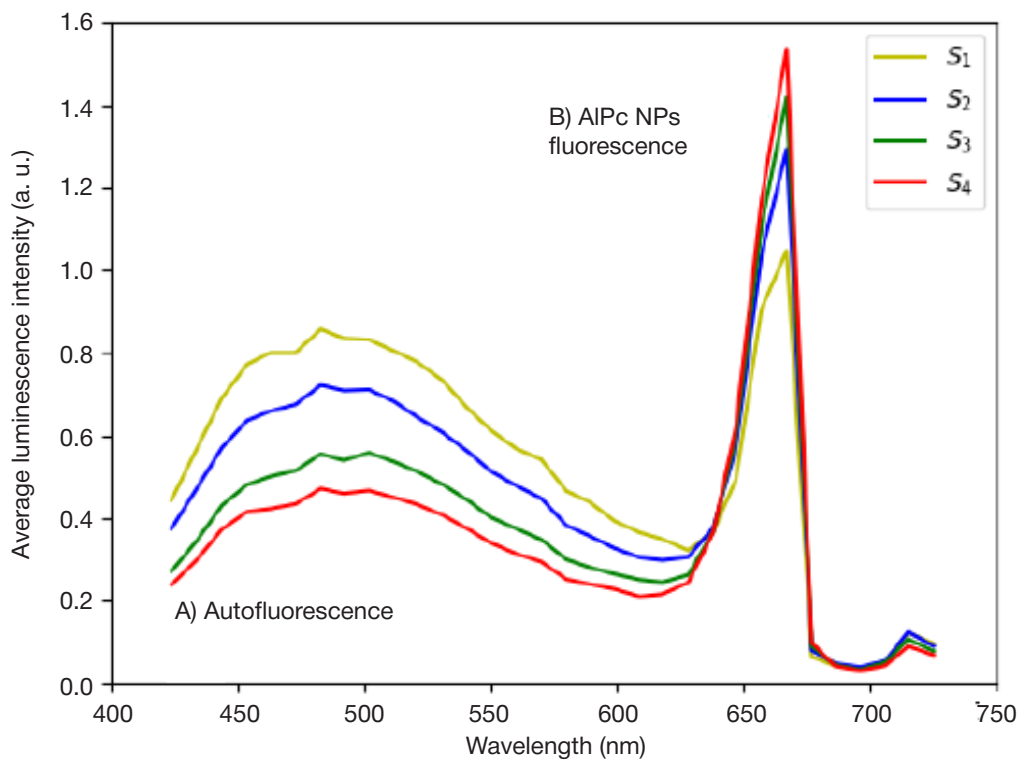

Fig. 3. The imaging of digital separation signals of (A) spectral image converted to RGB colors and (B) AlPc NPs fluorescence distribution. C. The fluorescence spectra recorded with the curve color corresponding to the highlighted areas. The spectra are normalized on each area's surface

A

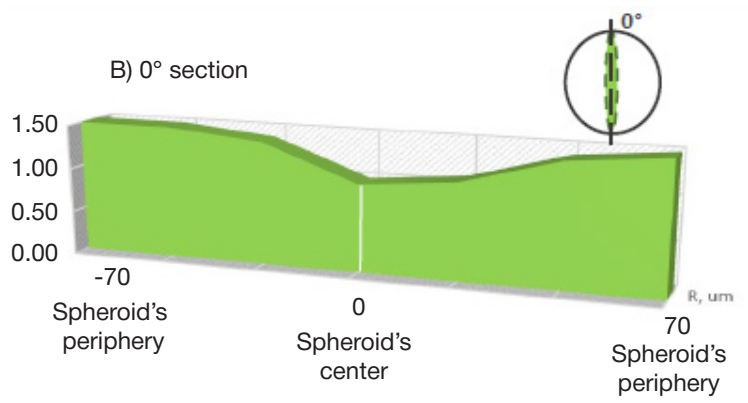

C

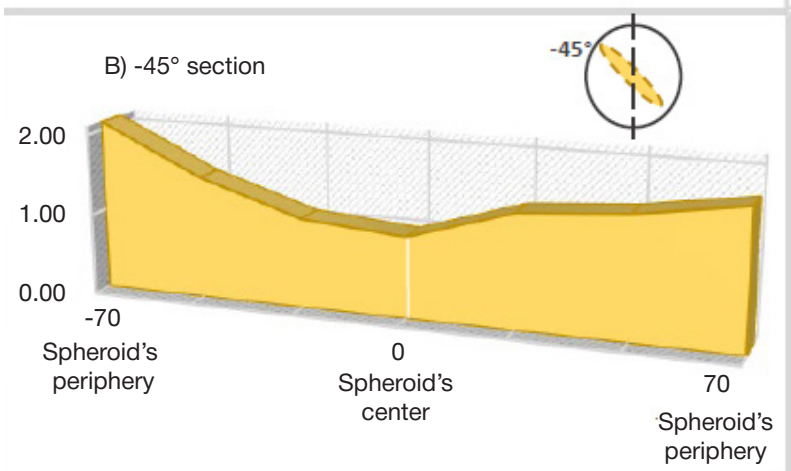

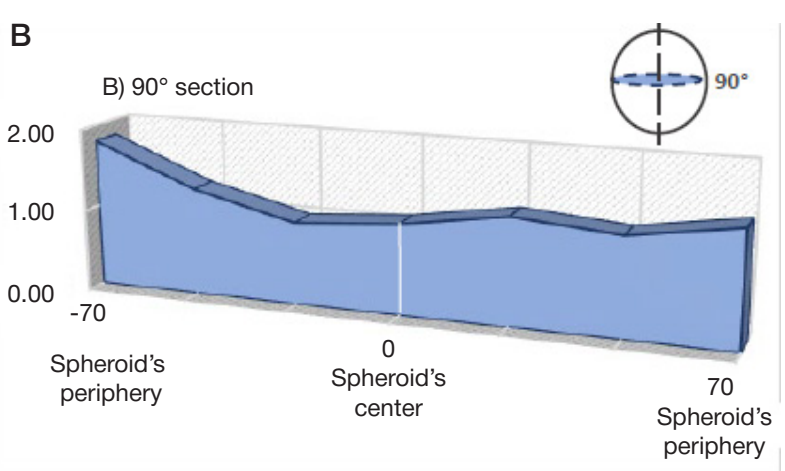

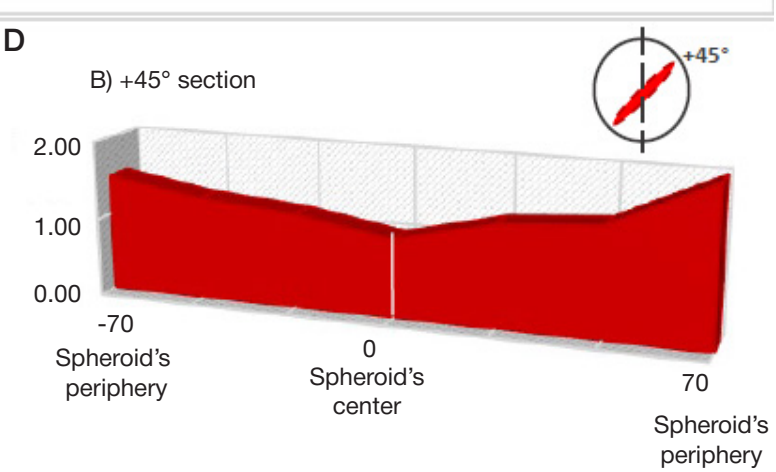

Fig. 4. The graphic representation of AIPc NPs uptake in the 4 spheroid sections: (A) $0^{\circ}$; (B) $90^{\circ}$; (C) $45^{\circ}$; (D) $-45^{\circ}$. It was calculated only from the PS fluorescence $\lambda_{\mathrm{fl}} \sim 670 \mathrm{~nm}\left(\lambda_{\mathrm{ex}} \sim 633 \mathrm{~nm}\right)$, excluding cell's autofluorescnence 
A

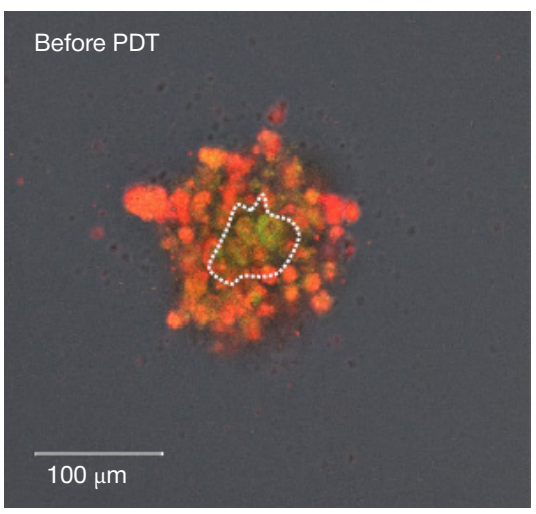

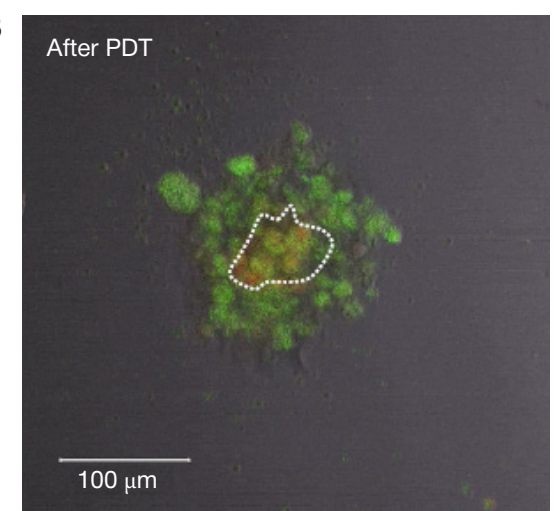

Fig. 5. Comparison of AlPc fluorescence before PDT (A) vs after PDT (B). Autofluorescence excitation $\lambda \sim 488 \mathrm{~nm}$, AlPc NPs fluorescence excitation $\lambda \sim 633$ nm.

A

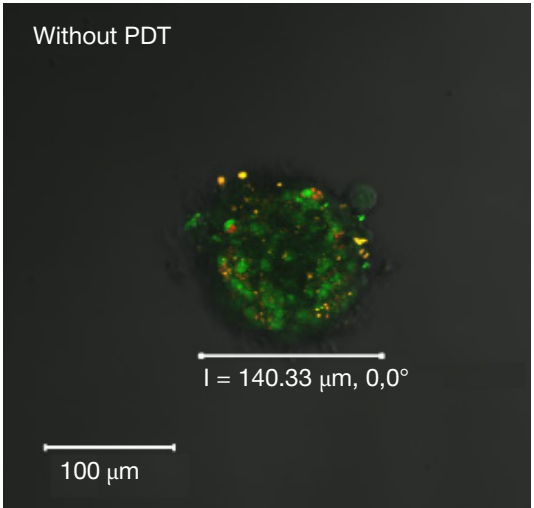

B $\quad$ After PDT

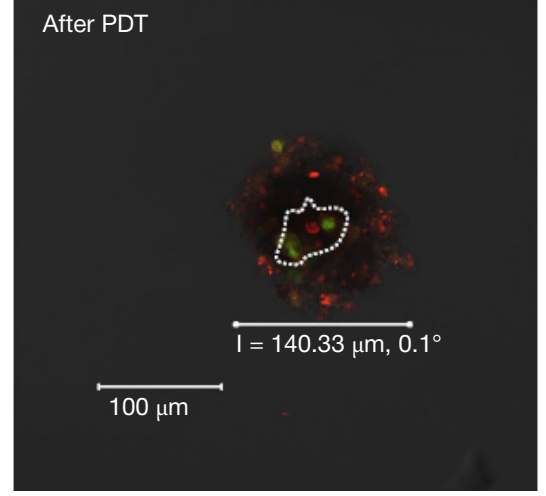

Fig. 6. Cell viability analysis after PDT, stained with acridine orange $(\mathrm{AO})$ (green — living cells) $(\mathbf{A})$ and propidium iodide (PI) (red — dead cells) (B). Excitation of AO fluorescence with $488 \mathrm{~nm}$ laser, excitation of $561 \mathrm{~nm}$ laser

before and after PDT. Analysing spheroid regions, the residual PS fluorescence signal was observed only in the core, while elsewhere the PS fluorescence was absent (Fig. 5). It can be related to the heterogeneous structure of spheroid with the various accessibility of deep layers to irradiation light and with different cells proliferation activity. In particular, this means that molecular oxygen is absent in the cental spheroid area, leading to limited photodynamic effect with partial fluorescence decline. Thus, the oxygen gradient in spheroids could be indirectly estimated analysing PS phototoxicity effects. That is also inherent to in vivo features of tumors such as hypoxia.

Finally, the photoxicity was estimated by analysing the spheroid cells viability using the living and dead cells staining. It was shown in comparison with staining of primary spheroid with green marked living cells (Fig. 6A). This evidence consists in the detection of green marking living cells only in the spheroid's core after PDT (Fig. 6B). At the same time red marked dead cells constitute the main bulk (Fig. 6B). It should be noted that the distribution of standard dye is homogeneous due the staining of cells viability only.

High PS accumulation and penetration are the most important characteristics responsible for anti-tumor efficiency. These characteristics must be carefully considered for novel PS screening. Furthermore, the main factor of incomplete tumor eradication is the PS heterogeneous distribution into the tumor. That is why the complex spatial and temporal distribution processes in tissues are especially important. The spheroid models allow simulating the penetration and intratumor transport of photosensitizer nanoparticles. Nowadays numerous nanoparticles have been studied for efficient and targeted PS delivery. The negative feature of some nanocarriers is the limited penetration, but presumably the size of nanoparticles matters significantly [18-19]. Summarazing the research results, the AIPC NPS are the promising PS with high phototoxicity and, more importantly, AIPC NPs are the probe for the inderect analysis of oxygen distribution, phenotype and metabolic cell processes. At the same time by the AIPC fluorescence estimation it was observed that the 3D multicellular model possesses primary in vivo features of tumors such as intercellular interaction, heterogeneity, hypoxia, oxygen and nutrient gradients. Thus, we suggest that in vitro spheroid model is a good predictive platform for studying the nanosized drugs, including the PS, prior to the animal models.

\section{CONCLUSION}

Our investigation clearly demonstrated an advantage of using AIPc nanoparticles as photosensitizer and multifunctional fluorescence probe. AIPC NPs have the sufficient capacity to accumulate, diffuse and penetrate into the spheroids. Microscopy techniques demonstrated that besides sufficient accumulation, AIPC NPS have the dynamic photoactivity depending on the bioenvironment. Particularly, AIPc NPs were used to evaluate the heterogeneity and to indirectly estimate the oxygen concentration, phenotype and metabolic cell processes. These are the most important parameters for the specific local nanophototheranostics. Received results should be useful for the other sighting studies of cell models, for example using the co-culture spheroids, which are taken into the account the immune response [20-24]. 
1. Breymayer J, Rück A, Ryabova AV, Loschenov VB, Steiner RW. Fluorescence Investigation of the Effect of Monocytes/ Macrophages and Skin Cells on Aluminium Phthalocyanine Nanoparticles. Journal Photodiagnosis and Photodynamic Therapy. 2014; 11(3): 380-90.

2. Vasilchenko SYu, Volkova Al, Ryabova AV, Loschenov VB, Konov VI, Mamedov AA et al. Application of aluminum phthalocyanine nanoparticles for fluorescent diagnostics in dentistry and skin autotransplantology. J Biophoton. 2010; 3 (5-6): 336-46.

3. Chiarante N, García Vior MC, Awruch J, Marino J, Roguin LP. Phototoxic action of a zinc (II) phthalocyanine encapsulated into poloxamine polymeric micelles in 2D and 3D colon carcinoma cell cultures. J Photochem Photobiol B. 2017; 170: 140-51.

4. Waite $\mathrm{CL}$, Roth CM. Nanoscale drug delivery systems for enhanced drug penetration into solid tumors: current progress and opportunities. Crit Rev Biomed Eng. 2012; 40: 21-41.

5. Kumari P, Jain S, Ghosh B, Zorin V, Biswas S. PolylactideBased Block Copolymeric Micelles Loaded with Chlorin e6 for Photodynamic Therapy: In Vitro Evaluation in Monolayer and 3D Spheroid Models. Mol Pharm. 2017 Nov 6; 14 (11): 3789-800.

6. Patel NR, Aryasomayajula B, Abouzeid AH, Torchilin VP. Cancer cell spheroids for screening of chemotherapeutics and drugdelivery systems. Ther Deliv. 2015; (6): 509-20.

7. Khanna S, Bhatt AN, Dwarakanath BS. Chapter 11 - multicellular spheroid: 3-D tissue culture model for cancer research A2. In: Ashish S Verma, Singh A, editors. Animal Biotechnology. San Diego: Academic Press, 2014; 195-210.

8. Kimlin LC, Casagrande G, Virador VMю In vitro three-dimensional (3D) models in cancer research: an update. Mol Carcinog. 2013; (52): 167-82

9. Baker BM, Chen CS. Deconstructing the third dimension: how 3D culture microenvironments alter cellular cues. J Cell Sci. 2012; (125): 3015-24.

10. Wartenberg $\mathrm{M}$ et al. Regulation of the multidrug resistance transporter P-glycoprotein in multicellular tumor spheroids by hypoxia-inducible factor (HIF-1) and reactive oxygen species. FASEB J. 2003; (17): 503-5.

11. Evans CL. Three-dimensional in vitro cancer spheroid models for photodynamic therapy: strengths and opportunities. Front Phys. 2015; 3 (15): 1-7.

\section{Литература}

1. Breymayer J, Rück A, Ryabova AV, Loschenov VB, Steiner RW. Fluorescence Investigation of the Effect of Monocytes/ Macrophages and Skin Cells on Aluminium Phthalocyanine Nanoparticles. Journal Photodiagnosis and Photodynamic Therapy. 2014; 11(3): 380-90.

2. Vasilchenko SYu, Volkova Al, Ryabova AV, Loschenov VB, Konov VI, Mamedov AA et al. Application of aluminum phthalocyanine nanoparticles for fluorescent diagnostics in dentistry and skin autotransplantology. J Biophoton. 2010; 3 (5-6): 336-46.

3. Chiarante N, García Vior MC, Awruch J, Marino J, Roguin LP. Phototoxic action of a zinc (II) phthalocyanine encapsulated into poloxamine polymeric micelles in 2D and 3D colon carcinoma cell cultures. J Photochem Photobiol B. 2017; 170: 140-51.

4. Waite CL, Roth CM. Nanoscale drug delivery systems for enhanced drug penetration into solid tumors: current progress and opportunities. Crit Rev Biomed Eng. 2012; 40: 21-41.

5. Kumari P, Jain S, Ghosh B, Zorin V, Biswas S. PolylactideBased Block Copolymeric Micelles Loaded with Chlorin e6 for Photodynamic Therapy: In Vitro Evaluation in Monolayer and 3D Spheroid Models. Mol Pharm. 2017 Nov 6; 14 (11): 3789-800.

6. Patel NR, Aryasomayajula B, Abouzeid AH, Torchilin VP. Cancer cell spheroids for screening of chemotherapeutics and drugdelivery systems. Ther Deliv. 2015; (6): 509-20.

7. Khanna S, Bhatt AN, Dwarakanath BS. Chapter 11 - multicellular spheroid: 3-D tissue culture model for cancer research A2. In:
12. Yakavets I, Yankovsky I, Millard M, Lamy L, Lassalle HP, Wiehe A et al. The alteration of temoporfin distribution in multicellular tumor spheroids by $\beta$-cyclodextrins. Int J Pharm. 2017; 529 (1-2): 568-75.

13. Ricketts KP, Cheema U, Nyga A, Castoldi A, Guazzoni $C$, Magdeldin T et al. A 3D in vitro cancer model as a platform for nanoparticle uptake and imaging investigations. 2014; 10 (19): 3954-61.

14. Kapinus VN, Kaplan MA, Yaroslavtseva-Isayeva EV, Spichenkova IS. Photodynamic therapy for head and neck basal cell skin cancer with additional interstitial laser irradiation. Biomedical Photonics. 2017; 6 (4): 20-6.

15. Abraham JA, Golubnitschaja O. Time for paradigm change in management of hepatocellular carcinoma: is a personalized approach on the horizon? Per Med. 2016; 13 (5): 455-67.

16. Hirschhaeuser F, Menne H, Dittfeld C, West J, Mueller-Klieser W, Kunz-Schughart LA. Multicellular tumor spheroids: an underestimated tool is catching up again. J Biotechnol. 2010; (148): 3-15

17. Josef LB, Boyle RW. Unique diagnostic and therapeutic roles of porphyrins and phthalocyanines in photodynamic therapy, imaging and theranostics. Theranostics. 2012; (2): 916-66.

18. Franken NAP, Rodermond HM, Stap J, Haveman J, van Bree C. Clonogenic assay of cells in vitro. Nat Protoc. 2006; (1): 2315-9.

19. Dreher MR, Liu W, Michelich CR, Dewhirst MW, Yuan F, Chilkoti A. Tumor vascular permeability, accumulation, and penetration of macromolecular drug carriers. J Natl Cancer Inst. 2006; (98): 335-44

20. Dobiasova M, Urbanova Z, Samanek M Relations between particle size of HDL and LDL lipoproteins and cholesterol esterification rate. Physiol Res Acad Sci Bohemoslov. 2005; (54): 159-65.

21. Kitamura T, Qian BZ, Pollard JW. Immune cell promotion of metastasis. Nat Rev Immunol. 2015; 15 (2): 73-86.

22. Kumar V, Patel S, Tcyganov E, Gabrilovich DI. The Nature of Myeloid-Derived Suppressor Cells in the Tumor Microenvironment. Trends Immunol. 2016; 37 (3): 208-20.

23. Long L, Yin M, Min W. 3D Co-culture System of Tumor-associated Macrophages and Ovarian Cancer. Cells Bio Protoc. 2018; 8 (8).

24. Sherman H, Gitschier HJ, Rossi AE. A novel three-dimensional immune oncology model for high-throughput testing of tumoricidal activity. Front Immunol. 2018 Apr 23; (9): 857.

Ashish S Verma, Singh A, editors. Animal Biotechnology. San Diego: Academic Press, 2014; 195-210.

8. Kimlin LC, Casagrande G, Virador VMю In vitro three-dimensional (3D) models in cancer research: an update. Mol Carcinog. 2013; (52): 167-82.

9. Baker BM, Chen CS. Deconstructing the third dimension: how 3D culture microenvironments alter cellular cues. J Cell Sci. 2012; (125): 3015-24

10. Wartenberg $\mathrm{M}$ et al. Regulation of the multidrug resistance transporter P-glycoprotein in multicellular tumor spheroids by hypoxia-inducible factor (HIF-1) and reactive oxygen species. FASEB J. 2003; (17): 503-5.

11. Evans $\mathrm{CL}$. Three-dimensional in vitro cancer spheroid models for photodynamic therapy: strengths and opportunities. Front Phys. 2015; 3 (15): 1-7.

12. Yakavets I, Yankovsky I, Millard M, Lamy L, Lassalle HP, Wiehe A et al. The alteration of temoporfin distribution in multicellular tumor spheroids by $\beta$-cyclodextrins. Int J Pharm. 2017; 529 (1-2): 56875.

13. Ricketts KP, Cheema U, Nyga A, Castoldi A, Guazzoni C, Magdeldin T et al. A 3D in vitro cancer model as a platform for nanoparticle uptake and imaging investigations. 2014; 10 (19): 3954-61.

14. Kapinus VN, Kaplan MA, Yaroslavtseva-Isayeva EV, Spichenkova IS. Photodynamic therapy for head and neck basal cell skin cancer 
with additional interstitial laser irradiation. Biomedical Photonics. 2017; 6 (4): 20-6.

15. Abraham JA, Golubnitschaja O. Time for paradigm change in management of hepatocellular carcinoma: is a personalized approach on the horizon? Per Med. 2016; 13 (5): 455-67.

16. Hirschhaeuser F, Menne H, Dittfeld C, West J, Mueller-Klieser W, Kunz-Schughart LA. Multicellular tumor spheroids: an underestimated tool is catching up again. J Biotechnol. 2010; (148): 3-15.

17. Josef LB, Boyle RW. Unique diagnostic and therapeutic roles of porphyrins and phthalocyanines in photodynamic therapy, imaging and theranostics. Theranostics. 2012; (2): 916-66.

18. Franken NAP, Rodermond HM, Stap J, Haveman J, van Bree C. Clonogenic assay of cells in vitro. Nat Protoc. 2006; (1): 2315-9.

19. Dreher MR, Liu W, Michelich CR, Dewhirst MW, Yuan F, Chilkoti A. Tumor vascular permeability, accumulation, and penetration of macromolecular drug carriers. J Natl Cancer Inst. 2006; (98): 335-44.

20. Dobiasova M, Urbanova Z, Samanek M Relations between particle size of HDL and LDL lipoproteins and cholesterol esterification rate. Physiol Res Acad Sci Bohemoslov. 2005; (54): 159-65.

21. Kitamura T, Qian BZ, Pollard JW. Immune cell promotion of metastasis. Nat Rev Immunol. 2015; 15 (2): 73-86.

22. Kumar V, Patel S, Tcyganov E, Gabrilovich DI. The Nature of Myeloid-Derived Suppressor Cells in the Tumor Microenvironment. Trends Immunol. 2016; 37 (3): 208-20.

23. Long L, Yin M, Min W. 3D Co-culture System of Tumor-associated Macrophages and Ovarian Cancer. Cells Bio Protoc. 2018; 8 (8).

24. Sherman H, Gitschier HJ, Rossi AE. A novel three-dimensional immune oncology model for high-throughput testing of tumoricidal activity. Front Immunol. 2018 Apr 23; (9): 857. 